\title{
Lawn irrigation with domestic wastewater by subsurface drip or sprinkling
}

\author{
Rafael Barcelos Mendonça ${ }^{1}$ (D), Roberto Lyra Villas Bôas ${ }^{1}$ (i), \\ Leandro José Grava de Godoy ${ }^{2 *}$ (D), Renan Lima de Sousa ${ }^{1}$ (1)
}

${ }^{1}$ Universidade Estadual Paulista (UNESP), Faculdade de Ciências Agronômicas, Departamento de Ciência Florestal, Solos e Ambiente, Botucatu-SP, Brazil

${ }^{2}$ Universidade Estadual Paulista (UNESP), Engenharia agronômica, Registro-SP, Brazil.

\begin{abstract}
To maintain the quality of a lawn and allow it to perform its functions (esthetics, enhancement of property, reduction of air temperature, etc.) efficient use of irrigation and adequate fertilization are necessary. The use of wastewater from sewage treatment, which has a nutrient load, in irrigation, can be an alternative especially if applied via subsurface, to reduce contamination risks. This study was conducted to examine the development and quality of an ornamental lawn of Zoysia japonica Steud (zoysiagrass) irrigated with wastewater depths, by two methods. The experiment was carried out in Botucatu-SP, Brazil, during winter and spring (June to December 2016). The treatments consisted of two irrigation methods (sprinkling and subsurface drip) and four domesticwastewater irrigation depths $(50 \%, 100 \%, 150 \%$ and $200 \%$ of the average daily evapotranspiration) plus control, where treated water was supplied by the Basic Sanitation Company of São Paulo State (Sabesp) of Botucatu, SP, Brazil, replacing 100\% of average daily evapotranspiration. The following characteristics were studied: clipping dry matter weight, relative chlorophyll content, lawn height, total coliforms and Escherichia coli in the plant tissue and nutrient concentration in the leaves. Subsurface drip irrigation with wastewater, using an irrigation depth of $100 \%$ of the average evapotranspiration, allowed an adequate development of the zoysiagrass lawn by maintaining its quality, without contamination by total coliforms or Escherichia coli.
\end{abstract}

Keywords: Zoysia spp., sewage treatment, fertigation, coliforms.

\section{Resumo}

Irrigação em gramado com água residuária doméstica por gotejamento subsuperficial ou aspersão

Para se manter a qualidade de um gramado e para que este exerça suas funções (estética, valorização do imóvel, redução temperatura do ar, etc.) se faz necessário o uso da irrigação de maneira racional e de adequada adubação. O uso da água residuária do tratamento de esgoto, que possui uma carga de nutrientes, na irrigação, pode ser alternativa, principalmente se aplicada via subsuperficial, para reduzir riscos de contaminação. Objetivou-se com esse trabalho avaliar o desenvolvimento e a qualidade de gramado ornamental com Zoysia japonica Steud, irrigado com lâminas de água residuária, por dois métodos. O trabalho foi realizado em Botucatu, SP, durante inverno e primavera (junho a dezembro de 2016). Os tratamentos consistiram em dois métodos de irrigação (aspersão e gotejamento subsuperficial) e quatro lâminas de água residuária doméstica $(50 \%, 100 \%, 150 \%$ e $200 \%$ da evapotranspiração média diária) e o controle com água tratada fornecida pela Sabesp de Botucatu, SP, repondo 100\% da evapotranspiração média diária. Foram estudadas as seguintes características: massa da matéria seca de aparas, índice relativo de clorofila, a altura do gramado, coliformes totais e Escherichia coli no tecido vegetal e concentração de nutriente nas folhas. A irrigação via gotejamento subsuperficial, com água residuária, utilizando $100 \%$ da lâmina média da evapotranspiração, permitiu desenvolvimento adequado do gramado com Zoysia japonica (grama esmeralda), mantendo a sua qualidade, e sem contaminação por coliformes totais e Escherichia coli.

Palavras-chave: Zoysia spp., tratamento de esgoto, fertirrigação, coliformes.

*Corresponding author: leandro.godoy@unesp.br 


\section{Introduction}

Among various existing grass species and cultivars, zoysiagrass (Zoysia japonica Steud) is the most widely sold and recommended for residential areas in Brazil. However, to maintain lawn quality, efficient irrigation as well as adequate fertilization are necessary. Irrigated grassy areas are mostly serviced by sprinklers, especially the retractable type, which does not compromise the esthetics and allows free transit over the lawn; as well as by mechanized mowers. Nonetheless, significant losses may occur due to runoff, drift and evaporation (Abed El-Bast et al., 2016). When using a subsurface drip system, water is applied directly to the root zone, avoiding these problems (Leinauer and Devitt, 2013). There is, however, a risk of emitters getting clogged (Silva et al., 2017), mainly when wastewater is used.

The reuse of domestic wastewater has been practiced in agriculture and considered an excellent measure to mitigate the problem of water scarcity, especially in areas surrounding cities. Use of wastewater in agriculture has grown in the last decades, as it is a natural nutrient source proven to improve the yield of irrigated crops. Owing to its significant nitrogen levels (20 to $70 \mathrm{mg} \mathrm{L}^{-1}$ ) (Ferreira et al., 2019), domestic wastewater can be a fertigation option for lawns, as $\mathrm{N}$ is an important nutrient to maintain good lawn quality (green color, density and recovery from disease, drought and stress caused by wear) (Caturegli et al., 2016). In Brazil, few studies have investigated lawn irrigation with wastewater, mainly by subsurface dripping.

The aim of this study was to evaluate the development of a Zoysia japonica lawn fertigated with domesticwastewater irrigation depths by two methods, as an alternative for the proper use of domestic wastewater.

\section{Material and Methods}

The experiment was carried out at the Department of Soils and Environmental Resources of the Faculty of Agronomic Sciences of Botucatu - Unesp (São Paulo State, University "Júlio de Mesquita Filho") (2250'48"S$48^{\circ} 26^{\prime} 07^{\prime \prime} \mathrm{W}, 817 \mathrm{~m}$ above sea level). The climate of the region is a Cfa type (subtropical, mesothermal, humid), according to the Köppen classification, characterized by cold, dry winters and hot, humid summers.

The soil in the area is classified as a Rhodic Ferralsol (Latossolo Vermelho Distrófico) of medium sandy texture. Samples of the $0-20-\mathrm{cm}$ layer were collected for chemical analysis following Raij et al. (2001) and particle-size analysis in accordance with Teixeira et al. (2017). The following properties were found: $\mathrm{pH}\left(\mathrm{CaCl}_{2}\right)$ - 3.9; $\mathrm{OM}$ $16 \mathrm{~g} \mathrm{dm}^{-3} ; \mathrm{P}$ (resin) - $5 \mathrm{mg} \mathrm{dm}^{-3} ; \mathrm{K}, \mathrm{Ca}, \mathrm{Mg}$ and $\mathrm{CEC}-$ $0.9,6,2$ and $58 \mathrm{mmol}_{\mathrm{c}} \mathrm{dm}^{-3}$, respectively; base saturation - 17\%; and sand, clay and silt - 792, 154, and $54 \mathrm{~g} \mathrm{~kg}^{-1}$, respectively.

The experiment was laid out in a split-plot design with four replicates, consisting of two irrigation systems (sprinkling and subsurface drip) as the main plot and four domestic wastewater (DW) irrigation depths $(50 \%, 100 \%$, $150 \%$, and $200 \%$ of the average daily evapotranspiration $[\mathrm{ADEv}])$ as subplots. Another treatment was installed (control), where treated water (TW) was supplied by the Sanitation Company of São Paulo State (Sabesp) of Botucatu, SP, Brazil, replacing 100\% of the ADEv. Each main plot measured $80 \mathrm{~m}^{2}$ and was divided into 20 subplots of $1.5 \mathrm{~m} \times 1.5 \mathrm{~m}$, with $0.5-\mathrm{m}$ spacing between the subplots.

For the conventional sprinkler system, each subplot was equipped with four Rain Bird ${ }^{\circledR} 1804$ retractable sprinklers $(15 \mathrm{~cm}$ high) containing a nozzle adjusted to release the water at a $90^{\circ}$ angle, flow rate of $0.07 \mathrm{~m}^{3} \mathrm{~h}^{-1}$ and pressure of $2 \times 10^{5} \mathrm{~N} \mathrm{~m}^{-2}$. For subsurface drip, the XFS-09-12-500 hose was installed with in-line drippers, with a flow rate of $3.48 \mathrm{~L} \mathrm{~h}^{-1}$, and a $17-\mathrm{mm}$ diameter tube, with emitters protected against root intrusion by the Copper Shield ${ }^{\mathrm{TM}}$ technology. Each subplot contained four $1.5-\mathrm{m}$ lines of the hose, which were spaced $0.375 \mathrm{~m}$ apart. Each row contained five drippers that were installed in a closed system, buried at a depth of $12 \mathrm{~cm}$. For the automation of the irrigation system, two Rain Bird ${ }^{\circledR}$ ESP - Modular controllers were used together with 100-DVF electric pulse (24 v) solenoid valves. Coupled to each controller, two rain sensors were installed to interrupt the irrigation whenever rainfall occurred exceeding $5 \mathrm{~mm}$. After the irrigation systems were installed, the area was limed with $335 \mathrm{~g} \mathrm{~m}^{-2}$ dolomitic limestone (PRNT 95\%) and fertilized one month later with $28.5 \mathrm{~g} \mathrm{~m}^{-2}$ of the 4-14-8 formulation. The Zoysia japonica cv 'Esmeralda ${ }^{\mathrm{TM}}$ ' was planted as sods immediately after fertilization.

Daily data on average daily evapotranspiration, precipitation and minimum, mean and maximum temperature were obtained from the meteorological station of Unesp during the experimental period, from May to December 2016 (Figures 1A and 1B). The average daily evapotranspiration data were calculated using the PenmanMonteith equation, which was used to define the daily irrigation depth to be applied, referring to the average weekly evapotranspiration. 


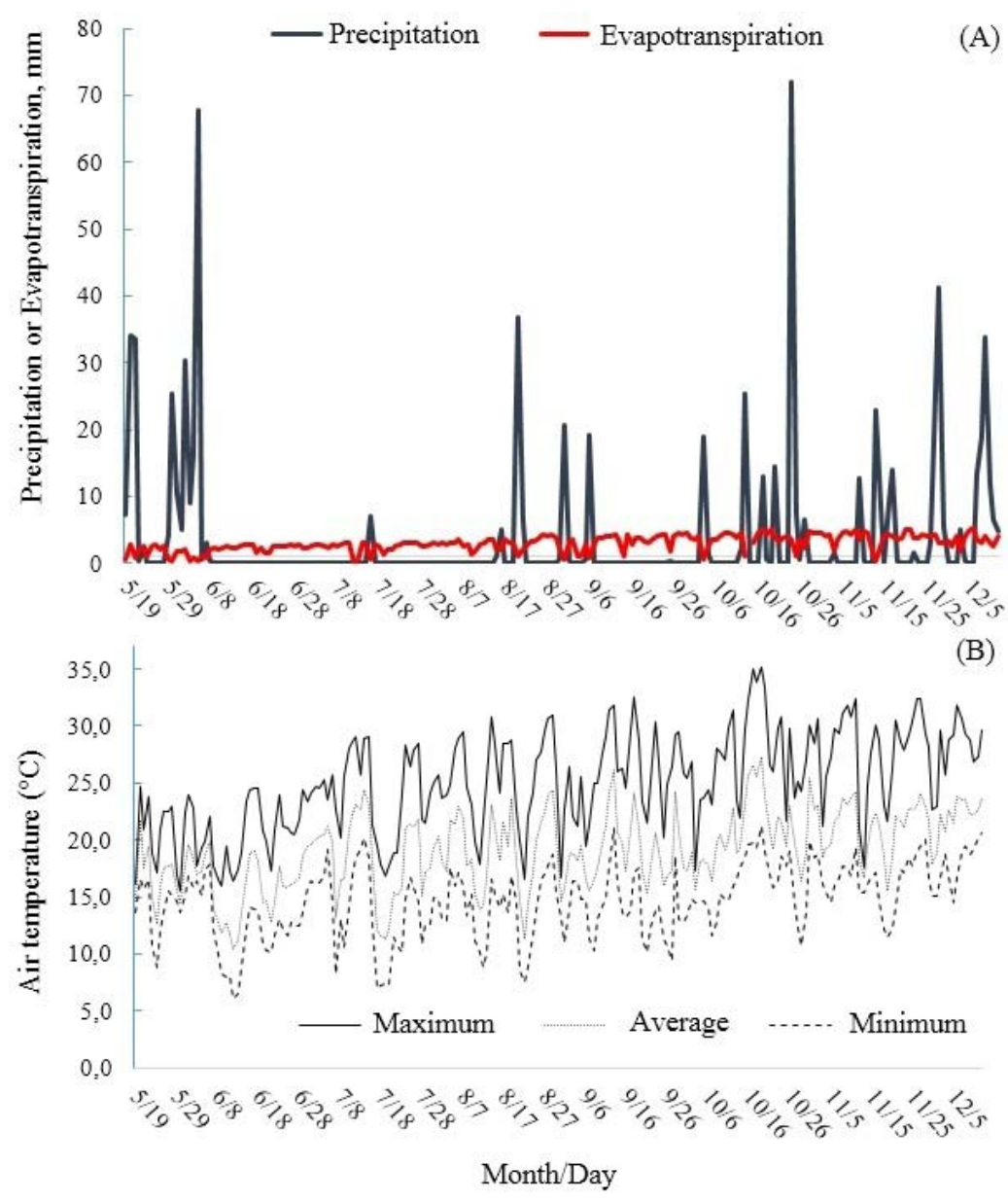

Figure 1. Precipitation, evapotranspiration and air temperature during the experimental period (Botucatu, SP, Brazil).

The domestic wastewater (DW) used in the experiment was provided by the Sewage Treatment Station of Botucatu, SP (Estação de Tratamento de Esgoto de Botucatu - ETE). The water was captured using a tank trailer coupled to a tractor and transported to the reservoir of the experiment. To pump the wastewater, a 0.5 -hp motor-pump set with a working pressure of $2.458 \times 10^{5} \mathrm{~Pa}$ and a flow rate of 2.7 $\mathrm{m}^{3} \mathrm{~h}^{-1}$ was used. The easel at the irrigation outlet had a 38,1 mm 100 mesh disk filter and a pressure gauge. Irrigation with DW started in May 2016, according to the treatments. From May to December 2016, DW samples were collected monthly and sent to the laboratory for nutrient content determination, using the adapted methodology of Malavolta et al. (1997), as well as $\mathrm{pH}$ and electrical conductivity (Table 1). Samples of treated water were also analyzed in May and December, following the same procedure. 
Table 1. Nutrient content, $\mathrm{pH}$ and electrical conductivity (EC) of domestic wastewater during the experiment and treated water at the start and end of the experiment

\begin{tabular}{|c|c|c|c|c|c|c|c|c|c|c|c|c|c|c|}
\hline \multirow{3}{*}{ Month } & \multicolumn{12}{|c|}{ Nutrient content } & \multirow{2}{*}{ pH } & \multirow{2}{*}{ EC } \\
\hline & $\mathbf{N}$ & $\mathbf{P}$ & $\mathbf{K}$ & $\mathbf{C a}$ & Mg & $\mathbf{S}$ & $\mathbf{N a}$ & B & $\mathbf{C u}$ & $\mathbf{F e}$ & Mn & $\mathbf{Z n}$ & & \\
\hline & \multicolumn{12}{|c|}{ 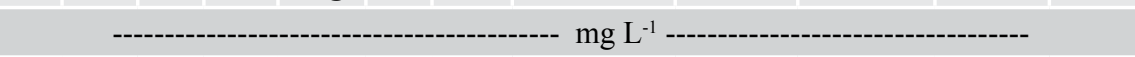 } & & $\mathrm{mS} \mathrm{dm}{ }^{-1}$ \\
\hline May & 40 & 2 & 20 & 26 & 3 & 10 & 45 & 0.03 & ND & 0.44 & 0.05 & ND & 7.17 & 0.596 \\
\hline June & 59 & 7 & 20 & 22 & 2 & 10 & 56 & 0.23 & ND & 0.11 & 0.00 & ND & 7.42 & 0.655 \\
\hline July & 60 & 1 & 20 & 25 & 3 & 13 & 65 & 0.06 & ND & 0.00 & 0.03 & ND & 7.23 & 0.726 \\
\hline August & 50 & 2 & 21 & 23 & 3 & 13 & 61 & 0.13 & ND & 0.14 & 0.04 & ND & 7.62 & 0.732 \\
\hline September & 57 & 2 & 26 & 25 & 3 & 13 & 46 & 0.10 & ND & 0.11 & 0.08 & ND & 7.96 & 0.769 \\
\hline October & 67 & 2 & 22 & 25 & 3 & 9 & 62 & 0.17 & ND & 0.11 & 0.04 & ND & 7.58 & 0.702 \\
\hline November & 61 & 2 & 21 & 24 & 4 & 10 & 96 & 0.05 & ND & 0.23 & 0.06 & ND & 8.06 & 0.676 \\
\hline December & 56 & 2 & 25 & 28 & 3 & 11 & 71 & 0.05 & ND & 0.32 & 0.08 & ND & 7.63 & 0.669 \\
\hline May & 2 & ND & 12 & 14 & 2 & 0 & 1,0 & ND & ND & ND & ND & ND & 6.57 & 0.041 \\
\hline December & 3 & ND & 14 & 15 & 2 & 0 & 1,1 & ND & ND & ND & ND & ND & 6.82 & 0.043 \\
\hline
\end{tabular}

ND- not detected.

The lawn was mowed fortnightly, to a height of 25 $\mathrm{mm}$, using the GreenMaster $1000^{\mathrm{TM}}$ (Toro) helical mower with a cutting collector box. Cuttings were collected from each subplot at 70, 135, 160 and 175 days after the start of treatments (DAS), packed in a paper bag and oven-dried for $72 \mathrm{~h}$ at $65{ }^{\circ} \mathrm{C}$ until the quantification of clipping dry matter weight using a precision scale.

Relative chlorophyll content (RCC) was determined on the grass leaves using the FieldScout CM-1000 portable chlorophyll meter, which was positioned $1 \mathrm{~m}$ above the lawn, allowing a sampled area of $82.8 \mathrm{~cm}^{2}$. The RCC was determined at $60,125,145$, and 160 DAS and recorded as the average of five readings, which were obtained at random in each subplot. Lawn height was measured using a Grass Height Prism Gauge ${ }^{\mathrm{TM}}$ (Turf-Tec). This measurement was carried out before some of the mowings (at 60, 100, 160, and 190 DAS).

In December, at the end of the experiment, total coliform and Escherichia coli counts were determined in the grass leaves. The area was prepared 15 days before the sample was removed and a 1-m tarp was installed, separating the irrigation systems so that there was no drift. Using gloves, masks and sterile scissors, $10 \mathrm{~g}$ of leaves were removed from the lawn of each subplot, starting with the control until the highest dose. These samples were packed in sterile plastic bags and sent to the Department of Microbiology and Immunology of the Institute of Biosciences at Unesp, Botucatu, SP, where a solution with $0.86 \%$ salt in deionized water was prepared. Ninety milliliters of this solution were added to the plastic bag, containing $10 \mathrm{~g}$ of plant tissue, which was then placed in a Stomacher ${ }^{\mathrm{TM}} 400$ Circulator machine for $30 \mathrm{~s}$, at 230 RPM. Subsequently, samples were sent to the water quality laboratory of the Department of Rural Engineering at FCA at Unesp, Botucatu, SP, for the count of total coliforms and Escherichia coli present in the samples, using the Colilert method (Lewis and Mak, 1989). Results were expressed as the most probable number (MPN) of organisms for $100 \mathrm{~mL}$ of sample. The cuttings obtained from the September mowings (135 DAS) were used to determine the macronutrient concentration, in accordance with the modified methodology of Malavolta et al. (1997).

Results were subjected to analysis of variance and, subsequently, to regression analysis, Tukey's test and contrast analysis at the 5\% probability level using Sisvar $^{\mathrm{TM}}$ software.

\section{Results and Discussion}

\section{Clippings dry matter weight}

The irrigation methods influenced dry matter weight on the first three evaluations, with higher values obtained with subsurface drip irrigation compared with sprinkling (Table 2). At 175 DAS, results were very similar. It is noteworthy that at 70 and 135 DAS, the treatment with DW by dripping provided a 3.2 and 3.9 times heavier clipping dry matter weight, respectively than sprinkling. Even when we compare only the systems with TW, drip irrigation provided greater grass growth in relation to the sprinkler, at all evaluation dates. 
Table 2. Summary of analysis of variance of the results of clipping dry matter weight according to the treatment.

\begin{tabular}{|c|c|c|c|c|}
\hline \multirow{2}{*}{ Source of variation } & \multicolumn{4}{|c|}{ Days after start of irrigation with the treatments } \\
\hline & 70 & 135 & 160 & 175 \\
\hline & \multicolumn{4}{|c|}{ 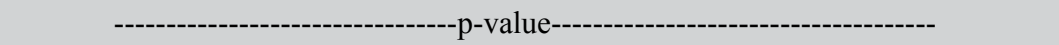 } \\
\hline Method (M) & 0.010 & 0.001 & 0.038 & 0.964 \\
\hline Depth (D) & 0.241 & 0.022 & 0.001 & 0.001 \\
\hline $\mathrm{M} \times \mathrm{D}$ & 0.469 & 0.387 & 0.709 & 0.121 \\
\hline CV1, \% & 51.54 & 27.17 & 30.75 & 24.17 \\
\hline \multirow{2}{*}{ CV $2, \%$} & 42.94 & 28.19 & 24.28 & 24.93 \\
\hline & \multicolumn{4}{|c|}{ 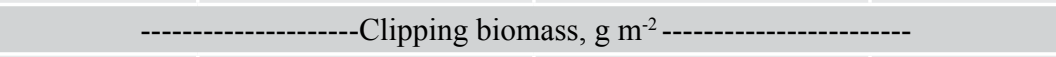 } \\
\hline Sprinkling (DW) & $17.2 \mathrm{~b}$ & $6.4 \mathrm{~b}$ & $210.3 \mathrm{~b}$ & $143.7 \mathrm{a}$ \\
\hline Subsurface drip (DW) & $55.2 \mathrm{a}$ & $25.2 \mathrm{a}$ & 310.9 a & $144.3 \mathrm{a}$ \\
\hline Sprinkling (TW) & $16.9 \mathrm{~b}$ & $7.4 \mathrm{~b}$ & $35.8 \mathrm{bB}$ & $12.2 \mathrm{bB}$ \\
\hline Subsurface drip (TW) & $54.0 \mathrm{a}$ & $28.6 \mathrm{a}$ & $89.7 \mathrm{aB}$ & $37.8 \mathrm{aB}$ \\
\hline Sprinkling $(100 \% \mathrm{DW})$ & 14.8 & 4.2 & $170.4 \mathrm{~A}$ & $126.8 \mathrm{~A}$ \\
\hline Subsurface drip (100\% DW) & 56.6 & 22.9 & $262.8 \mathrm{~A}$ & $129.2 \mathrm{~A}$ \\
\hline
\end{tabular}

DW - domestic wastewater; TW - treated water. Means followed by uppercase letters in the column do not differ from each other, by contrast, when compared with the means of the treatment with TW and the treatment with a $100 \%$ DW depth, according to the test. Means followed by lowercase letters in the column do not differ from each other according to Tukey's test at the $5 \%$ level when the irrigation methods are compared, using the same type of water.

Although there was no significant interaction between irrigation systems and DW depths, regression analysis revealed a linear response of average clipping weight to the DW depths when applied via drip irrigation. Based on the angular coefficients of the equations, the plant biomass was estimated to increase by $0.16,0.07,1.84$, and $0.64 \mathrm{~g}$ at $70,135,160$, and $175 \mathrm{DAS}$, respectively, with every $1 \%$ of irrigation depth applied (Table 3 ). The higher dry matter accumulation rates at the end of the experiment were due to the higher air temperatures. The increasing grass growth observed with the increasing DW depths is due, in large part, to its nutrient load, considering that at depth of $100 \%$
ADEv, applied via drip irrigation, the grasses accumulated up to 10 times more mass when compared with treatment with TW at the same irrigation depth. Domestic wastewater contributed to the greater nutrient accumulation in millet plants, representing an alternative for reducing the demand for water and the use of chemical fertilizers (Reis et al., 2019). Thus, the largest accumulation of dry matter in zoysia grass was provided by the application of the highest DW depth via subsurface dripping. However, for ornamental lawns, increased growth is not a highly desired feature, as it will require a higher mowing frequency - in other words, greater maintenance. 
Table 3. Summary of regression analysis of the results of clipping dry matter weight on the evaluated dates according to the irrigation depths and irrigation methods applied.

\begin{tabular}{|c|c|c|c|c|c|c|}
\hline \multirow{2}{*}{ Method } & \multicolumn{4}{|c|}{ Irrigation depth (\%) } & \multirow{2}{*}{ Regression } & \multirow{2}{*}{$\mathbf{R}^{2}, \%$} \\
\hline & 50 & 100 & 150 & 200 & & \\
\hline \multicolumn{7}{|c|}{ Clipping dry matter weight, $g$} \\
\hline \multicolumn{7}{|c|}{70 days after start of irrigation with the treatments } \\
\hline Sprinkling & 15.5 & 14.8 & 16.5 & 22.1 & $\mathrm{~ns}$ & - \\
\hline Subsurface drip & 38.4 & 56.6 & 62.8 & 62.9 & $0.05 \mathrm{~L}^{1}$ & 78.68 \\
\hline \multicolumn{7}{|c|}{135 days after start of irrigation with the treatments } \\
\hline Sprinkling & 5.7 & 4.2 & 6.4 & 9.4 & ns & - \\
\hline Subsurface drip & 20.0 & 22.9 & 28.3 & 29.5 & $0.01 \mathrm{~L}^{2}$ & 94.95 \\
\hline \multicolumn{7}{|c|}{160 days after start of irrigation with the treatments } \\
\hline Sprinkling & 66.0 & 170.4 & 255.1 & 349.6 & ns & - \\
\hline Subsurface drip & 188.2 & 262.8 & 316.0 & 476.6 & $0.05 \mathrm{~L}^{3}$ & 94.04 \\
\hline \multicolumn{7}{|c|}{175 days after start of irrigation with the treatments } \\
\hline Sprinkling & 45.3 & 126.8 & 159.3 & 192.4 & ns & - \\
\hline Subsurface drip & 96.2 & 129.2 & 172.4 & 230.1 & $0.01 \mathrm{~L}^{4}$ & 99.97 \\
\hline \multicolumn{2}{|c|}{${ }^{1} \hat{y}=35.34375+0.1588 x^{*}$} & & \multicolumn{3}{|c|}{${ }^{3} \hat{y}=81.26875+1.83696 x^{*}$} & \\
\hline \multicolumn{2}{|c|}{${ }^{2} \hat{y}=16.69125+0.06804 x^{* *}$} & & \multicolumn{3}{|c|}{${ }^{4} \hat{y}=63.47+0.641535 x^{* *}$} & \\
\hline
\end{tabular}

L - linear; Q - quadratic; ns - not significant; *,** and *** - significant at the 5,1 and $0.1 \%$ probability levels. Means followed by common letters do not differ from each other according to Tukey's test at the $5 \%$ level.

\section{Lawn height}

Lawn height differed between the irrigation depths from 100 days after the start of irrigation (DAS). For the irrigation method $\times$ depth interaction $(\mathrm{M} \times \mathrm{D})$, differences were only seen at 60 DAS, with the highest values obtained at the irrigation depths greater than or equal to $150 \% \mathrm{ADEv}$ in the drip method. Lawn height increased linearly as the levels were elevated in the subsurface drip system (Tables 4 and 5).

Table 4. Summary of analysis of variance of the results of lawn height according to the treatment.

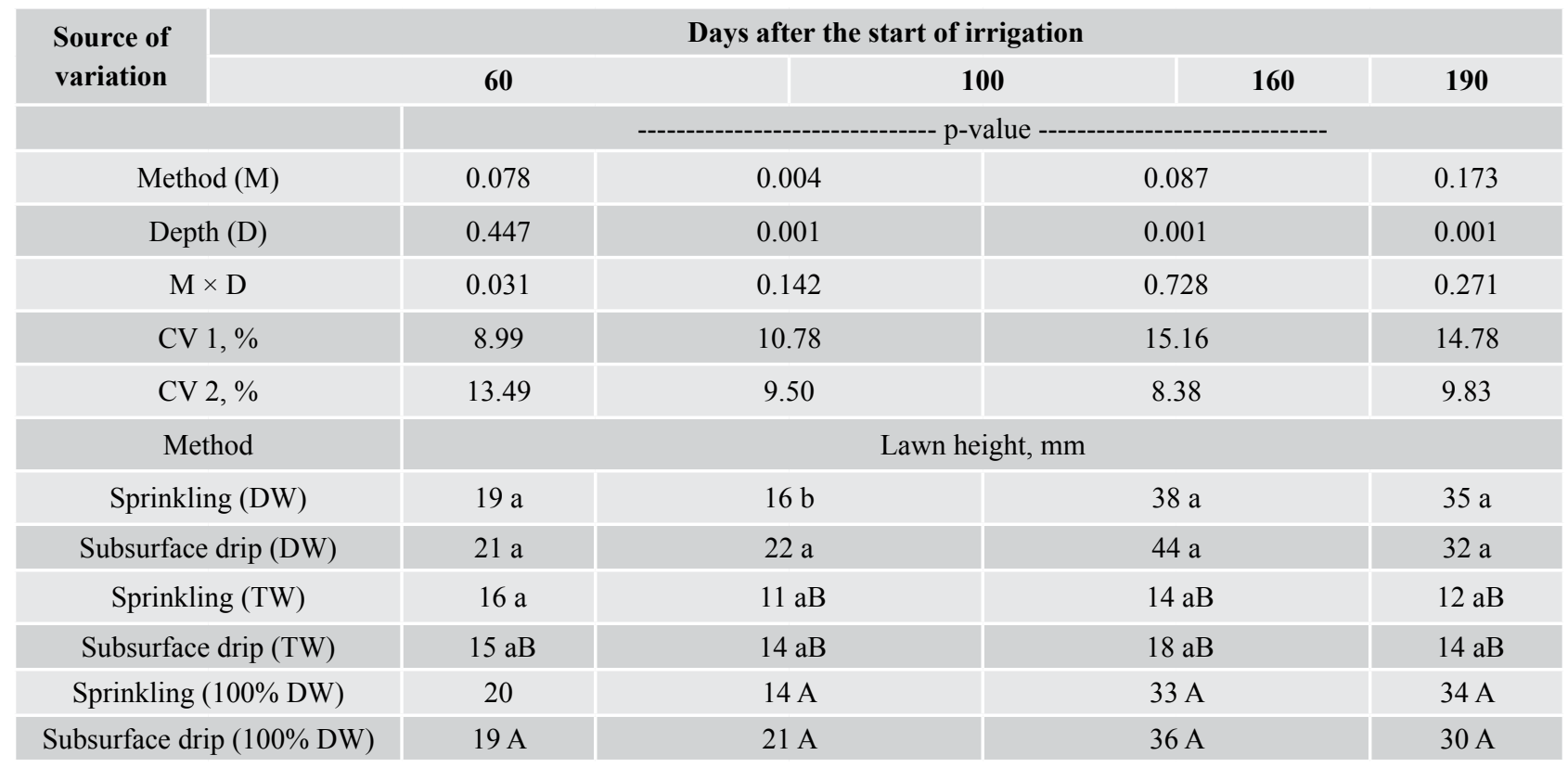

DW - domestic wastewater; TW - treated water. Means followed by uppercase letters in the column do not differ from each other, by contrast, when compared with the means of the treatment with TW and the treatment with a $100 \%$ DW depth, according to the $t$ test. Means followed by lowercase letters in the column do not differ from each other according to Tukey's test at the $5 \%$ level when the irrigation methods are compared, using the same type of water. 
Table 5. Summary of regression analysis of lawn height on the evaluated dates according to the irrigation depth applied.

\begin{tabular}{|c|c|c|c|c|c|c|}
\hline \multirow{3}{*}{ Method } & \multicolumn{4}{|c|}{ Average lawn height, mm } & \multirow{3}{*}{ Regression } & \multirow{3}{*}{$\mathbf{R}^{2}(\%)$} \\
\hline & \multicolumn{4}{|c|}{ Irrigation depth (\%) } & & \\
\hline & 50 & 100 & 150 & 200 & & \\
\hline & \multicolumn{6}{|c|}{60 days after the start of irrigation } \\
\hline Sprinkling & $19 \mathrm{a}$ & $20 \mathrm{a}$ & $18 \mathrm{~b}$ & $18 \mathrm{~b}$ & ns & - \\
\hline \multirow[t]{2}{*}{ Subsurface drip } & $18 \mathrm{a}$ & $19 \mathrm{a}$ & $23 \mathrm{a}$ & $23 \mathrm{a}$ & $0.01 \mathrm{~L}^{1}$ & 89.0 \\
\hline & \multicolumn{6}{|c|}{100 days after the start of irrigation } \\
\hline \multirow[t]{2}{*}{ Mean } & 14 & 17 & 20 & 25 & $0.001 \mathrm{~L}^{2}$ & 99.4 \\
\hline & \multicolumn{6}{|c|}{160 days after the start of irrigation } \\
\hline \multirow[t]{2}{*}{ Mean } & 27 & 34 & 41 & 63 & $0.001 \mathrm{~L}^{3}$ & 90.31 \\
\hline & \multicolumn{6}{|c|}{190 days after the start of irrigation } \\
\hline Mean & 24 & 32 & 36 & 41 & $0.001 \mathrm{~L}^{4}$ & 98.23 \\
\hline \multicolumn{4}{|c|}{${ }^{1} \hat{y}=16.125+0.039 x^{* *}$} & \multicolumn{3}{|c|}{${ }^{3} \hat{y}=13.3125+0.2275 x^{* * *}$} \\
\hline \multicolumn{3}{|c|}{${ }^{2} \hat{y}=10.1875+0.073 x^{* * *}$} & \multicolumn{4}{|c|}{$4 \hat{y}=20.25+0.107 x^{* * *}$} \\
\hline
\end{tabular}

L - linear; Q - quadratic; ns - not significant; *,** and *** - significant at the 5, 1 and $0.1 \%$ probability levels. Means followed by common letters in the column do not differ from each other according to Tukey's test at the $5 \%$ level.

The plant height values indicate two very distinct periods: the first at 60 and 100 DAS, when the grass height ranged between 16 and $22 \mathrm{~mm}$; and the second, which was characterized by the highest temperature, when plant height varied from 32 to $44 \mathrm{~mm}$. It is important to stress, however, that the mowing period was different between the measurements, which were performed at intervals of 60 , 40,60 , and 30 days after each mowing.

For the irrigation depth of $100 \%$ ADEv, a comparison can be made between the treatments where DW and TW were applied. The lawn was taller in the plots irrigated with DW, both by drip irrigation and sprinkling, when compared with the grass irrigated with TW. This greater plant growth can be attributed to the presence of ions, mainly $\mathrm{N}$, found in larger amounts in DW (average $56 \mathrm{mg} \mathrm{L}^{-1}$ ), as $\mathrm{N}$ is considered the main nutrient responsible for shoot growth, in lawns (Gazola et al., 2016, Lima et al., 2018, Mota et al., 2019).

Lawn height rose linearly as the DW depths were increased, regardless of irrigation method, i.e., the grass was taller where a greater water volume and a larger amount of nutrients were applied. As was discussed for the accumulation of dry matter, the increased height provided by higher irrigation depths is not a desirable characteristic for the grass, since this increased shoot growth will result in greater expenditure on mowing (Gazola et al., 2016). The heights reached by the lawn in the treatments were within the range deemed adequate by Patton et al. (2017) for grasses of the genus Zoysia (13 to $63 \mathrm{~mm}$ ). According to Christians et al. (2016), it is recommended to maintain Zoysia japonica grass at a height of 15 to $30 \mathrm{~mm}$. Using the $100 \%$ ADEv depth, grass height was maintained between 17 and $34 \mathrm{~mm}$, which is very close to ideal, whereas higher depths would require a higher mowing frequency to maintain the ideal height (Table 5). The 200\% ADEv depth provided a grass height of $63 \mathrm{~mm}$, at $160 \mathrm{DAS}$.

A caveat should be emphasized, however, that the plots with drip irrigation were not homogeneous in grass height. Therefore, the grass nearest the dripper was taller (Figure 2). This effect can be minimized by reducing the distance between the drip lines, which, in this case, was $38 \mathrm{~cm}$. 


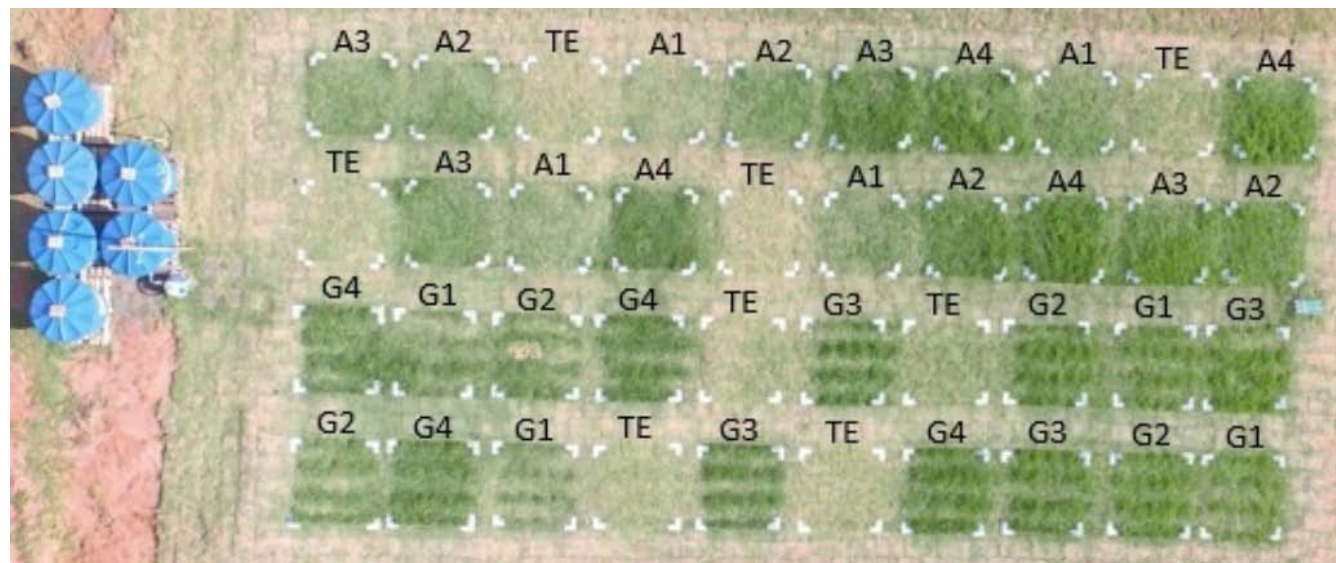

Figure 2. Aerial photo of the experiment with treatment captions. A - sprinkling; $\mathrm{G}$ - subsurface drip; 1, 2, 3 and $4-50 \%, 100 \%, 150 \%$, and $200 \%$ of the average daily evapotranspiration, respectively; TE - treated water. Photo: Gomes, Mendonça (2016).

\section{Relative chlorophyll content (RCC)}

Higher RCCs were observed in the treatments using the drip irrigation method compared with the sprinkler, only at the beginning of the experiment (60 DAS). On all evaluation dates, the RCC of the lawn was higher when irrigation was performed using DW than with TW. The domestic wastewater had a N content of 40 to $67 \mathrm{mg}$ $\mathrm{L}^{-1}$, whereas the treated water contained only 2 to $3 \mathrm{mg}$ $\mathrm{L}^{-1}$ of $\mathrm{N}$ (Table 1). Nitrogen is one of the main nutrients influencing the chlorophyll content of plants, as it is part of the chlorophyll molecule as well as of various compounds involved in the synthesis of the pigment (Malavolta et al., 1997).

In the sprinkling system, RCC increased during the evaluation period, with the highest value observed at 190 DAS. When the lawn was drip-irrigated, the highest RCC was attained earlier, at 145 DAS, indicating superior $\mathrm{N}$ utilization efficiency with this irrigation system. It must be considered, however, that there might have been a higher chlorophyll content in the grasses near the drip line (Figure 2), which generated these higher rates (Table 6).

Table 6. Summary of analysis of variance of the results of relative chlorophyll content according to the treatment.

\begin{tabular}{|c|c|c|c|c|}
\hline & \multicolumn{4}{|c|}{ Days after start of irrigation with the treatments } \\
\hline & 60 & 125 & 145 & 190 \\
\hline & \multicolumn{4}{|c|}{ 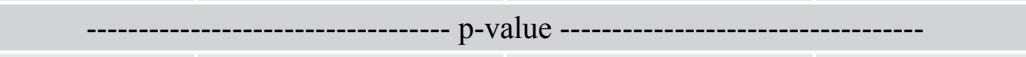 } \\
\hline Method (M) & 0.047 & 0.535 & 0.367 & 0.117 \\
\hline Depth (D) & 0.405 & 0.001 & 0.001 & 0.001 \\
\hline $\mathrm{M} \times \mathrm{D}$ & 0.816 & 0.743 & 0.481 & 0.112 \\
\hline CV $1, \%$ & 5.22 & 22.24 & 21.81 & 18.97 \\
\hline CV $2, \%$ & 12.21 & 13.68 & 11.31 & 12.44 \\
\hline Method & \multicolumn{4}{|c|}{ 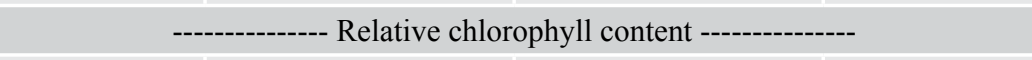 } \\
\hline Sprinkling (DW) & $139 \mathrm{~b}$ & 278 a & $455 \mathrm{a}$ & 487 a \\
\hline Subsurface drip (DW) & 147 a & 294 a & $494 \mathrm{a}$ & 421 a \\
\hline Sprinkling (TW) & $112 \mathrm{aB}$ & $142 \mathrm{aB}$ & $176 \mathrm{aB}$ & $176 \mathrm{aB}$ \\
\hline Subsurface drip (TW) & $102 \mathrm{aB}$ & $139 \mathrm{aB}$ & $171 \mathrm{aB}$ & $169 \mathrm{aB}$ \\
\hline Sprinkling (100\% DW) & $142 \mathrm{~A}$ & $247 \mathrm{~A}$ & $437 \mathrm{~A}$ & $504 \mathrm{~A}$ \\
\hline Subsurface drip (100\% DW) & $147 \mathrm{~A}$ & $274 \mathrm{~A}$ & $461 \mathrm{~A}$ & $400 \mathrm{~A}$ \\
\hline
\end{tabular}

DW - domestic wastewater; TW - treated water. Means followed by uppercase letters in the column do not differ from each other, by contrast, when compared with the means of the treatment with TW and the treatment with a $100 \%$ DW depth, according to the $t$ test. Means followed by lowercase letters in the column do not differ from each other according to Tukey's test at the $5 \%$ level when the irrigation methods are compared, using the same type of water. 
There was a linear increase in RCC, which is attributed to the contribution from water. However, this result is mainly due to the nutrients in the water, especially $\mathrm{N}$, present in a greater concentration-, besides $\mathrm{Mg}$. Considering the angular coefficient of the generated equations, each $1 \%$ of the applied irrigation depth would provide increases of $1.2,1.9,1.2$ in RCC at 125, 145 and 190 DAS, respectively (Table 7). Increasing RCC values in response to application of N-containing products was also observed by Gazola et al.
(2016), Lima et al. (2018) and Mota et al. (2019). Lima et al. (2012) indicated, for bermudagrass cv. 'Celebration', a species with a darker green color than Zoysia cv. 'Esmeralda', adequate RCC values as 374 to 471 chlorophyll units. In the present experiment, from 145 DAS onwards, RCC values higher than those were obtained using irrigation depths equal to or greater than $100 \% \mathrm{ADEv}$. In other words, there is no need for irrigation depths greater than $100 \%$ to obtain an adequate green color (Figure 2).

Table 7. Summary of regression analysis of relative chlorophyll content on the evaluated dates according to the irrigation depth applied.

\begin{tabular}{|c|c|c|c|c|c|c|}
\hline \multirow{3}{*}{ Method } & \multicolumn{4}{|c|}{ Relative chlorophyll content } & \multirow{3}{*}{ Regression } & \multirow{3}{*}{$\mathrm{R}^{2}(\%)$} \\
\hline & \multicolumn{4}{|c|}{ Irrigation depth (\%) } & & \\
\hline & 50 & 100 & 150 & 200 & & \\
\hline \multicolumn{7}{|c|}{60 days after the start of irrigation } \\
\hline Mean (Spk and Ssd) & 136 & 144 & 141 & 151 & ns & - \\
\hline \multicolumn{7}{|c|}{125 days after the start of irrigation } \\
\hline Mean (Spk and Ssd) & 205 & 261 & 290 & 388 & $0.001 \mathrm{~L}^{1}$ & 94.73 \\
\hline \multicolumn{7}{|c|}{145 days after the start of irrigation } \\
\hline Mean (Spk and Ssd) & 318 & 449 & 506 & 626 & $0.001 \mathrm{~L}^{2}$ & 98.01 \\
\hline \multicolumn{7}{|c|}{190 days after the start of irrigation } \\
\hline Mean (Spk and Ssd) & 348 & 452 & 481 & 535 & $0.001 \mathrm{~L}^{3}$ & 93.92 \\
\hline${ }^{1} \hat{y}=141.4375+1.159 x * * *$ & & & \multicolumn{3}{|c|}{${ }^{3} \hat{y}=307+1.1795 x^{* * *}$} & \\
\hline${ }^{2} \hat{y}=230.25+1.959 x * * *$ & & & & & & \\
\hline
\end{tabular}

L - linear; Q - quadratic; ns - not significant; *,** and *** - significant at the 5,1 and $0.1 \%$ probability levels. Spk - sprinkling; Ssd - subsurface drip.

Based on the irrigation depth applied and the average $\mathrm{N}$ concentration present in DW, it was possible to calculate the amount of $\mathrm{N}$ applied to the soil in each treatment. In the eight months of experiment, the irrigation depths of $50 \%$, $100 \%, 150 \%$ and $200 \%$ ADEv corresponded to $703 ; 1,364$; 1,924; and 2,440 L of water per treatment in each subplot and the respective average $\mathrm{N}$ doses of 170, 340, 480, and $610 \mathrm{~kg} \mathrm{ha}^{-1}$. Thus, the irrigation depth of $100 \% \mathrm{ADEv}$, with DW, which was sufficient to maintain adequate green color as well as adequate growth (dry matter accumulation and height) corresponded to the $\mathrm{N}$ dose of $340 \mathrm{~kg} \mathrm{ha}^{-1}$. Schwartz et al. (2018) found the average $\mathrm{N}$ dose of 171 $\mathrm{kg} \mathrm{ha}^{-1}$ as adequate for grasses of the genus Zoysia, for the state of Florida, USA, using mineral nitrogen fertilizer. In Brazil, Gazola et al. (2016) considered the N dose of 100 to $200 \mathrm{~kg} \mathrm{ha}^{-1}$ as adequate for Zoysia cv. Esmeralda. The $\mathrm{N}$ dose applied with the irrigation depth of $100 \%$ of ADEv can meet the annual requirement of zoysiagrass in less than a year, even in sandier soil.

\section{Total coliforms and Escherichia coli}

In the application of DW by sprinkling, the MPN of total coliforms and Escherichia coli were at the upper limit of the reading table, that is, $214.3 \times 10^{-4} \mathrm{MPN} / 100 \mathrm{~mL}$. The opposite occurred for the drip irrigation method, where the results were less than $100 \mathrm{MPN} / 100 \mathrm{~mL}$, which was also found in the control treatment, without DW. Application by subsurface drip can make it difficult for pathogens to access the soil surface, keeping them close to the emitter, in the soil, and not in the plant tissue. Similar results were obtained by Cuba et al. (2015), who cultivated lettuce in a hydroponic system using domestic sewage effluent, where the shoots had no contact with the solution. Based on the obtained values, we may infer that application of water via drip irrigation, even with a high coliform content, does not reach the shoots, serving as a protection for the plant and those that benefit from it.

\section{Leaf nutrient content}

The P, B, Fe and Mn contents in the leaf varied with the irrigation methods, and the DW depths influenced the levels of N, P, K, Fe and $\mathrm{Mn}$. The $\mathrm{Ca}, \mathrm{Mg}, \mathrm{S}, \mathrm{Cu}$ and $\mathrm{Zn}$ levels in the zoysia grass leaves were not affected by the treatments (Tables 8 and 9). 
Table 8. Summary of analysis of variance of the results of macronutrient content in the lawn leaves in September (135 days after the start of treatments), according to the treatment.

\begin{tabular}{|c|c|c|c|c|c|c|}
\hline & $\mathbf{N}$ & $\mathbf{P}$ & $\mathbf{K}$ & $\mathbf{C a}$ & Mg & $\mathbf{S}$ \\
\hline & \multicolumn{6}{|c|}{ 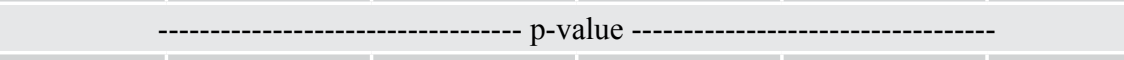 } \\
\hline Method (M) & 0.898 & 0.008 & 0.193 & 0.272 & 0.495 & 0.439 \\
\hline Depth (D) & 0.001 & 0.001 & 0.043 & 0.850 & 0.436 & 0.583 \\
\hline$M \times D$ & 0.324 & 0.039 & 0.480 & 0.301 & 0.125 & 0.770 \\
\hline $\mathrm{CV} 1, \%$ & 3.29 & 4.82 & 11.75 & 37.45 & 15.74 & 7.25 \\
\hline \multirow[t]{2}{*}{$\mathrm{CV} 2, \%$} & 6.42 & 11.05 & 9.55 & 28.05 & 14.03 & 5.78 \\
\hline & \multicolumn{6}{|c|}{ 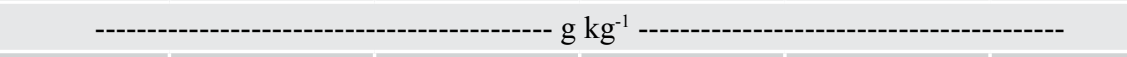 } \\
\hline Sprinkling (DW) & $24.4 \mathrm{a}$ & $2.0 \mathrm{a}$ & $9.0 \mathrm{~A}$ & 4.9 & 1.4 & 2.1 \\
\hline Subsurface drip (DW) & $24.4 \mathrm{a}$ & $1.8 \mathrm{~b}$ & $7.3 \mathrm{~B}$ & 5.8 & 1.5 & 2.2 \\
\hline Sprinkling (TW) & $21.6 \mathrm{aB}$ & $1.7 \mathrm{aA}$ & $10.3 \mathrm{~A}$ & 6.4 & 1.6 & 2.0 \\
\hline Subsurface drip (TW) & $17.3 \mathrm{bB}$ & $1.6 \mathrm{aB}$ & $11.5 \mathrm{~A}$ & 6.1 & 1.3 & 2.1 \\
\hline Sprinkling $(100 \% \mathrm{DW})$ & $24.5 \mathrm{~A}$ & $1.9 \mathrm{~A}$ & $9.0 \mathrm{~A}$ & 4.5 & 1.3 & 2.1 \\
\hline Subsurface drip (100\% DW) & $23.7 \mathrm{~A}$ & $1.9 \mathrm{~A}$ & $7.3 \mathrm{~B}$ & 6.7 & 1.5 & 2.2 \\
\hline
\end{tabular}

DW - domestic wastewater; TW - treated water. Means followed by uppercase letters in the column do not differ from each other, by contrast, when compared with the means of the treatment with TW and the treatment with a $100 \%$ DW depth, according to the $t$ test. Means followed by lowercase letters in the column do not differ from each other according to Tukey's test at the 5\% level when the irrigation methods are compared, using the same type of water.

Table 9. Summary of analysis of variance of the results of micronutrient content in the lawn leaves in September (135 days after the start of treatments), according to the treatment.

\begin{tabular}{|c|c|c|c|c|c|}
\hline & B & $\mathbf{C u}$ & $\mathbf{F e}$ & Mn & Zn \\
\hline Method (M) & 0.001 & 0.267 & 0.018 & 0.021 & 0.264 \\
\hline Depth (D) & 0.769 & 0.366 & 0.047 & 0.011 & 0.616 \\
\hline $\mathrm{M} \times \mathrm{D}$ & 0.577 & 0.939 & 0.390 & 0.516 & 0.765 \\
\hline CV $1, \%$ & 23.44 & 7.78 & 35.90 & 11.71 & 13.41 \\
\hline \multirow[t]{2}{*}{$\mathrm{CV} 2, \%$} & 17.58 & 10.22 & 54.5 & 11.21 & 8.26 \\
\hline & \multicolumn{5}{|c|}{ 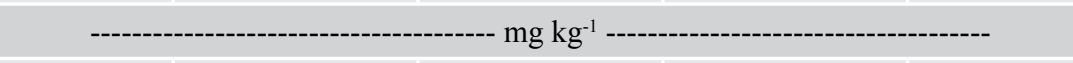 } \\
\hline Sprinkling (DW) & $4.3 \mathrm{~b}$ & 13.1 & 1957 a & $99.9 \mathrm{a}$ & $22.8 \mathrm{a}$ \\
\hline Subsurface drip (DW) & $12.1 \mathrm{a}$ & 13.6 & $1059 \mathrm{~b}$ & $83.1 \mathrm{~b}$ & $21.4 \mathrm{a}$ \\
\hline Sprinkling (TW) & $5.5 \mathrm{~b}$ & 14.3 & $4135 \mathrm{a}$ & $112.3 \mathrm{a}$ & $23.0 \mathrm{a}$ \\
\hline Subsurface drip (TW) & $13.9 \mathrm{a}$ & 13.5 & $2655 \mathrm{a}$ & $85.8 \mathrm{~b}$ & $20.3 \mathrm{~b}$ \\
\hline Sprinkling $(100 \% \mathrm{DW})$ & 3.9 & 12.8 & 1583 & 102.0 & 23.5 \\
\hline Subsurface drip (100\% DW) & 12.0 & 13.3 & 908 & 84.5 & 21.5 \\
\hline
\end{tabular}

DW - domestic wastewater; TW - treated water. Means followed by uppercase letters in the column do not differ from each other, by contrast, when compared with the means of the treatment with TW and the treatment with a $100 \%$ DW depth, according to the $t$ test. Means followed by lowercase letters in the column do not differ from each other according to Tukey's test at the $5 \%$ level when the irrigation methods are compared, using the same type of water. 
Phosphorus was significantly affected by the $\mathrm{M} \times \mathrm{D}$ interaction, with higher contents obtained by sprinkling with DW compared with drip irrigation, at the highest depths (Table 10). The leaf Fe and Mn contents were also higher in the sprinkling treatments than with drip irrigation, both with DW and TW. This result may be related to the low mobility of $\mathrm{P}, \mathrm{Fe}$ and $\mathrm{Mn}$ in the soil, which limits their absorption by plants closer to the drip line, and the foliar absorption of these nutrients, which is more effective than via soil, since water would always remain on the leaves after irrigation. Additionally, these nutrients have low mobility in the plant. As for B, which is a very mobile element in the soil, because of the lack of charge of its main absorbed form $\left(\mathrm{B}(\mathrm{OH})_{3}\right)$ (Dhassi et al., 2019), the highest leaf content of this nutrient was observed in the drip irrigation systems, both with DW and TW.

Table 10. Summary of regression analysis of nutrient content in the lawn leaf according to the irrigation depth applied.

\begin{tabular}{|c|c|c|c|c|c|c|}
\hline \multirow{3}{*}{ Method } & \multicolumn{4}{|c|}{ Average macronutrient content, $\mathrm{g} \mathrm{kg}^{-1}$} & \multirow{3}{*}{ Regression } & \multirow{3}{*}{$\mathbf{R}^{2}(\%)$} \\
\hline & \multicolumn{4}{|c|}{ Irrigation depth (\%) } & & \\
\hline & 50 & 100 & 150 & 200 & & \\
\hline \multicolumn{7}{|c|}{$\mathrm{N}$} \\
\hline Mean (Spk and Ssd) & 21.9 & 24.1 & 25.4 & 26.1 & $0.001 \mathrm{~L}^{1}$ & 94,93 \\
\hline \multicolumn{7}{|c|}{$P$} \\
\hline Sprinkling & $1.6 \mathrm{a}$ & $1.9 \mathrm{a}$ & $2.3 \mathrm{a}$ & $2.4 \mathrm{a}$ & $0.001 \mathrm{~L}^{2}$ & 96,89 \\
\hline Subsurface drip & $1.7 \mathrm{a}$ & $1.9 \mathrm{a}$ & $1.8 \mathrm{~b}$ & $1.9 \mathrm{~b}$ & $\mathrm{~ns}$ & - \\
\hline \multicolumn{7}{|l|}{ 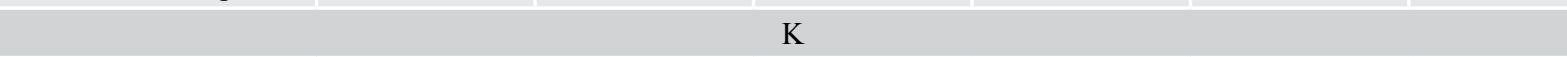 } \\
\hline Sprinkling & $9.5 \mathrm{a}$ & $10.3 \mathrm{a}$ & $11.3 \mathrm{a}$ & $11.4 \mathrm{a}$ & $0.05 \mathrm{~L}^{3}$ & 90,62 \\
\hline Subsurface drip & $10.7 \mathrm{a}$ & $11.5 \mathrm{a}$ & $11.1 \mathrm{a}$ & $12.1 \mathrm{a}$ & ns & - \\
\hline \multicolumn{7}{|c|}{$\mathrm{Ca}$} \\
\hline Mean (Spk and Ssd) & 5.5 & 5.6 & 5.0 & 5.3 & ns & - \\
\hline \multicolumn{7}{|c|}{$\mathrm{Mg}$} \\
\hline Sprinkling & $1.3 \mathrm{a}$ & $1.3 \mathrm{a}$ & $1.5 \mathrm{a}$ & $1.6 \mathrm{a}$ & $0.05 \mathrm{~L}^{4}$ & 94,6 \\
\hline Subsurface drip & $1.5 \mathrm{a}$ & $1.5 \mathrm{a}$ & $1.4 \mathrm{a}$ & $1.5 \mathrm{a}$ & ns & - \\
\hline \multicolumn{7}{|l|}{ 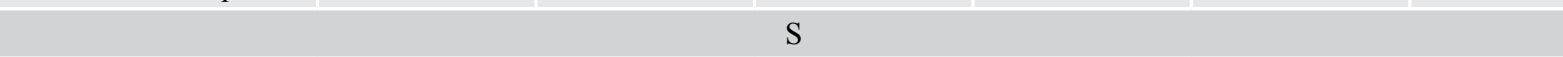 } \\
\hline Mean (Spk and Ssd) & 2.1 & 2.1 & 2.1 & 2.2 & ns & - \\
\hline \multicolumn{7}{|c|}{ B } \\
\hline Mean (Spk and Ssd) & 8.3 & 7.9 & 8.6 & 8.0 & ns & - \\
\hline \multicolumn{7}{|c|}{$\mathrm{Cu}$} \\
\hline Mean (Spk and Ssd) & 13.3 & 13.3 & 13.4 & 13.5 & $\mathrm{~ns}$ & - \\
\hline \multicolumn{7}{|c|}{$\mathrm{Fe}$} \\
\hline Sprinkling & $3159.8 \mathrm{a}$ & $1481.3 \mathrm{a}$ & $1583.0 \mathrm{a}$ & $1607.5 \mathrm{a}$ & $0.05 \mathrm{~L}^{5}$ & 53.61 \\
\hline Subsurface drip & $1400.0 \mathrm{~b}$ & $1090.3 \mathrm{a}$ & $908.8 \mathrm{a}$ & $837.0 \mathrm{a}$ & $\mathrm{ns}$ & - \\
\hline \multicolumn{7}{|c|}{$\mathrm{Mn}$} \\
\hline Sprinkling & $114.8 \mathrm{a}$ & $102.0 \mathrm{a}$ & $93.3 \mathrm{a}$ & $89.8 \mathrm{a}$ & $0.01 \mathrm{~L}^{6}$ & 94.23 \\
\hline Subsurface drip & $89.3 \mathrm{~b}$ & $84.5 \mathrm{~b}$ & $79.3 \mathrm{a}$ & $79.3 \mathrm{a}$ & ns & - \\
\hline \multicolumn{7}{|c|}{$\mathrm{Zn}$} \\
\hline Mean & 22.1 & 22.5 & 22.4 & 21.4 & ns & - \\
\hline \multicolumn{3}{|c|}{${ }^{1} \hat{y}=20.9125+0.027738 x^{* * *}$} & \multicolumn{4}{|c|}{$\hat{y}=1.125+0.00235 x^{*}$} \\
\hline \multicolumn{3}{|c|}{${ }^{2} \hat{y}=1.39875+0.00512 x^{* * *}$} & \multicolumn{4}{|c|}{${ }^{5} \hat{y}=3096.625-9.11 x^{*}$} \\
\hline \multicolumn{3}{|c|}{${ }^{3} \hat{y}=8.95+0.013 x^{*}$} & \multicolumn{4}{|c|}{${ }^{6} \hat{y}=20.875-0.1675 x^{* *}$} \\
\hline
\end{tabular}

L - linear; Q - quadratic; ns - not significant; *,** and *** - significant at the 5, 1 and 0.1\% probability levels. Spk - sprinkling; Ssd - subsurface drip. Means followed by lowercase letters in the column do not differ from each other according to Tukey's test at the 5\% level when the irrigation methods are compared, using the same type of water. 
No difference was detected between the irrigation systems for the leaf $\mathrm{N}$ content. However, considering only $\mathrm{TW}$, a lower $\mathrm{N}$ content was obtained with the sprinkling system, despite the low $\mathrm{N}$ levels in this water (Table 1). Comparing only the treatments at the irrigation depth of $100 \%$, between TW and DW, a higher $\mathrm{N}$ content was obtained with DW using both irrigation methods, and a higher P content was obtained with drip irrigation. Although DW has higher K contents than TW, the leaf K content was lower in the treatment with DW in the drip system. This effect may have been due to the higher Ca content in DW, which can occupy the colloid charges, making $\mathrm{K}$ more susceptible to leaching and, therefore, less available to the plant, besides competitive inhibition during absorption (Fernandes et al., 2019).

There was a linear increase in the leaf $\mathrm{P}, \mathrm{K}$ and $\mathrm{Mg}$ contents as the reused-water irrigation depths were increased when applied via sprinkling; and in the leaf $\mathrm{N}$ content regardless of the irrigation system, which shows that DW can be an efficient means to provide these nutrients for grasses. In terms of micronutrients, the leaf Fe and $\mathrm{Mn}$ contents decreased with the increasing depths applied via sprinkling, probably due to the competitive inhibition with sodium, which is the element present at the highest concentration in DW, together with $\mathrm{N}$ (Table 1).

The treatments with DW irrigation depths greater than $100 \%$ ADEv provided adequate leaf nutrient contents, except for $\mathrm{S}$ and $\mathrm{Zn}$, in which the leaves were deficient (Shadoxx, 2017). Regarding $\mathrm{Zn}$, the presence of this nutrient in DW was not detected in the analysis, whereas $\mathrm{S}$, despite being present in DW at concentrations higher than $\mathrm{P}$ and $\mathrm{Mg}$, was not sufficient to meet the plant's requirements, likely because it is easily leachable and grasses have their roots more concentrated in the surface layer. Very high Fe, $\mathrm{Mn}$, and $\mathrm{Cu}$ contents were also found in the leaf, which was not due to irrigation with DW, since the treatments with TW also showed high levels of those nutrients, but rather due to contamination with soil particles.

\section{Conclusions}

Subsurface drip irrigation with wastewater at $100 \%$ of the average daily evapotranspiration depth allowed proper development of lawn with Zoysia japonica (zoysiagrass), maintaining its quality, with no contamination by total coliforms or Escherichia coli.

\section{Author contribution}

RBM: preparation of the introduction, methodology and tables of results. Interpretation and discussion of results; RLVB: elaboration of the methodology and critical review; LJGG: contribution to the introduction, statistical analysis, interpretation and discussion of results, and critical review; RLS: formatting of the article and contribution to the discussion of results.

\section{Acknowledgments}

The authors thank the Coordination for the Improvement of Higher Education Personnel - CAPES for the fellowship grant; Rain Bird ${ }^{\circ}$, for supplying all the irrigation equipment; the Rain Bird ${ }^{\circledR}$ managers José Giacoia Neto and Marcelo Zlochevsky for their support, help and teachings to the support of the Tutorial Education Program (PET); and the SS Gramas e Paisagismo company for the grass provided.

\section{References}

ABED EL-BAST, A.M.; KASSEM, M.E.; ABUARA, M.A. Characterization of water application uniformity, runoff and wind drift evaporation losses under center pivot irrigation system. Misr Journal of Agricultural Engineering, v.33, n.3, p.821-848, 2016. DOI: https://doi. org/ 10.21608/mjae.2016.97733

CATUREGLI, L; CORNIGLIA, M.; GAETANI, M.; GROSSI, N.; MAGNI, S.; MIGLIAZZI, M.; ANGELINI, L.; MAZZONCINI, M.; SILVESTRI, N.; FONTANELLI, M.; RAFFAELLI, M.; PERUZZI, A.; VOLTERRANI, M. Unmanned aerial vehicle to estimate nitrogen status of turfgrasses. PLoS One, v.11, n.6, 2016. DOI: https://doi. org/10.1371/journal.pone.0158268

CHRISTIANS, N.E.; PATTON, A.J.; LAW, Q.D. Fundamentals of Turfgrass Management - Fifth Edition. New York: John Wiley \& Sons, 2017. 482p.

CUBA, R.S.; DO CARMO, J.R.; SOUZA, C.F.; BASTOS, R.G. Potencial de efluente de esgoto doméstico tratado como fonte de água e nutrientes no cultivo hidropônico de alface. Revista Ambiente \& Água, v.10, n.3, p.574-586, 2016. DOI: https://doi.org/10.4136/ambi-agua.1575.

DHASSI, K.; DRISSI, S.; MAKROUM, K.; ER-REZZA, H.; AMLAL, F.; AÏT HOUSSA, A. Soil boron migration as influenced by leaching rate and soil characteristics: a column study, Communications in Soil Science and Plant Analysis, v.50, n.14, p.1663-1670, 2019 DOI: https://doi.or $\mathrm{g} / 10.1080 / 00103624.2019 .1631333$

FERNANDES, M.S.; SOUZA, S.R.; SANTOS, L.A. (Eds.) Nutrição Mineral de Plantas, 2ed, Viçosa: Sociedade Brasileira de Ciência do Solo, 2019. 670p.

FERREIRA, D.M.; NAVONI, J.A.; ARAÚJO, A.L.C., TINOCO, J.D.; AMARAL, V.S. Wastewater use in agriculture: analytical limits of sewage for impact control in Brazil. Revista Caatinga, v.32, n.4, p.1048-1059, 2019. DOI: https://doi.org/10.1590/1983-21252019v32n421rc. 
GAZOLA, R.P.D.; BUZETTI, S.; GAZOLA, R.N.; CASTILHO, R.M.M.; TEIXEIRA FILHO, M.C.M.; CELESTRINO, T.S.; DUPAS, E. Intensidade da coloração verde das folhas da grama esmeralda submetida a doses de nitrogênio e ao uso de herbicidas como reguladores de crescimento. Ciência Rural, v. 46, n.6, p. 984-990, 2016. DOI: https://doi.org/10.1590/0103-8478cr20150276.

LEINAUER, B.; D.A. DEVITT. Irrigation science and technology. In: HORGAN, B.; STIER, J.; BONOS, S., Agronomy Monograph 56. Madison: ASA, CSSA, and SSSA, 2013. p.1075-1133.

LEWIS, C.M.; MAK, J.L. Comparison of membrane filtration and Autoanalysis Coliert presence-absence techniques for analysis of total coliforms and Escherichia coli in drinking water samples. Applied and Environmental Microbiology, v.55, n.12, p. 3091-3094, 1989.

LIMA, C.P.; BACKES, C.; FERNANDES, D.M.; SANTOS, A.J.M.; GODOY, L.J.G.; VILLAS BÔAS, R.L. Uso de índices de reflectância das folhas para avaliar o nível de nitrogênio em grama-bermuda. Ciência Rural, v.42, n.9, p.1568-1574, 2012. DOI: https://doi.org/10.1590/ S0103-84782012005000062

LIMA, C.P.; BACKES, C.; SANTOS, A.J.M.; VILLAS BÔAS, R.L.; FERNANDES, D.M.; GODOY, L.J.G.; OLIVEIRA, M.R. Sod production and the effects of liquid organo-mineral fertilizers and thickness of sod. Scientia Agricola, v.75, n.4, p.346-353, 2018. DOI: https://doi. org/10.1590/1678-992x-2016-0320.

MALAVOLTA, E.; VITTI, G.C.; OLIVEIRA, S.A. Avaliação do estado nutricional das plantas princípios e aplicações. 2ed. Piracicaba: Potafos, 1997. 319p.

MOTA, F.D.; VILLAS BOAS, R.L.; MATEUS, C.M.D.; SILVA, T.B.G. Sewage sludge compost in zoysia grass sod production. Revista Ambiente \& Água, v.14, n.1, p. 1-10, 2019. DOI: https://doi.org/10.4136/ambi-agua.2301
PATTON, A.J.; SCHWARTZ, B.M.; KENWORTHY, K.E. Zoysiagrass (Zoysia spp.) history, utilization, and improvement in the United States: A Review. Crop Science, v.57, p.37-72, 2017. DOI: https://doi.org/10.2135/ cropsci2017.02.0074.

RAIJ, B.; ANDRADE, J.C.; CANTARELLA, H.; QUAGGIO, J.A. Análise química para avaliação da fertilidade de solos tropicais. Campinas: Instituto Agronômico, 2001. 285p.

REIS, M. M.; SILVA, A.J.; SANTOS, L.D.T.; LOPES, E.M.G.; BARROS, R.E.; DONATO, L.M.S. Irrigação de milheto com água residuária tratada: Resposta de trocas gasosas e acúmulo de nutriente. Ciência e Agrotecnologia, v.43, p.1-10, 2019. DOI: http://dx.doi.org/10.1590/14137054201943023519.

SCHWARTZ, B.; ZHANG, J.; KENWORTHY, K.; MILlER, G.; PEACOCK, C.; SLADEK, B.; CHRISTENSEN, C. Nitrogen rate and mowing height affect seasonal performance of Zoysiagrass cultivars. Agronomy Journal, v.110, p.2114-2123, 2018. DOI: https:// doi.org/10.2134/agronj2018.01.0006.

SHADDOX, T.W. Tissue testing and interpretation for Florida turfgrasses. 2017. SL 181-B: Available at: <http:// edis.ifas.ufl.edu/ep539> Accessed on: March, $26^{\text {th }} 2020$.

SILVA, P.F.; MATOS, R.M.; LIMA, S.C.; DANTAS NETO, J.; LIMA, V.L.A. Obstruction and uniformity in drip irrigation systems by applying treated wastewater. Revista Ceres, v.64, n.4, p.344-350, 2017. DOI: https:// doi.org/10.1590/0034-737x201764040002

TEIXEIRA, P.C.; DONAGEMMA, G.K.; FONTANA, A.; TEIXEIRA, W.G. Manual de métodos de análise de solo, 3ed. Brasília: Embrapa, 2017. 573p. 